\title{
PROFESSIONAL DEVELOPMENT OF TEACHERS THROUGH INVOLVEMENT IN ACTION RESEARCH
}

\begin{abstract}
Towards the end of the twentieth century in education appeared three functional concepts, which are based on the participatory approach to research: action research, participatory research, participatory-action research. It seems that these types of research would be of great use to teachers in the classroom. Several educational policy documents stipulate the idea of lifelong learning. Starting with 1996, the European Year of Lifelong Learning, the Lifelong Learning Strategy is formulated, which talks about the need to develop the professional potential of each person and the teaching / learning methods. But professional development is an ongoing process and requires a huge effort from teachers and the whole community. At the same time, teachers are always concerned with finding solutions to overcome students' learning problems, avoid school failure, reduce functional illiteracy, etc. In this article we propose some suggestions for the development of literacy and research skills in students, which we consider more important in the instructional process. We would like to mention that there is currently an increasing emphasis on transdisciplinary or integrated training. Only through a constructive collaboration with colleagues from all school subjects will we be able to carry out valuable research and change the precarious situation in the direction of obtaining performance. In the 21st century, the teacher appears as an agent of change, which implies that he will be the basic element of educational reforms.
\end{abstract}

Keywords: professional development, action research, participatory research, participatory action research, functional illiteracy, school failure. 
Next we will describe the three types of research, which should be applied in the activity of teachers: action research, participatory research, participatory action research. The founder of the concept of action research Kurt Lewin (1948) argued, "that an investigation whose purpose is only the production of books, without the immediate influence of reality, is inadequate." (Nedelcu, 2011, p. 33). Promoting this type of research, Lewin was convinced that through concrete actions, an immediate change of the detected problem is possible. It also insisted on the idea of involving practitioners at all stages of the investigation. This type of research has an advantage by reducing the time between confirming the results of the investigation and carrying them out at a certain time. The obtained results can be implemented in the educational activity even during the investigation, being incomplete or well structured, and then other issues can be highlighted and researched in more detail.So, action research is determined by an atypical situation, by the feeling that something is wrong, that something needs to be changed. In those situations, the intuitive search strategy works and for this reason, in the research action, initially there are no clear finalities. The teacher has the role of an experienced researcher, who helps students to identify actions of change, without engaging in them.

Participatory research differs from action research, because in this case the teacher-researcher selects the group of interested people and collaborates with them to study social reality. It unites different people in terms of training, age, occupation around a problem of common interest. Its objective is to capitalize on personal experience and that of others through critical reflections on the results. In participatory research, the systematic search strategy is applied because it is more complex, focuses on monitoring the research process and involves intuition and reason alike. Research and guidance teachers have the skills to organize their work so as to stimulate cooperation. The participatory approach can be extended beyond the walls of the school, including parents and other members of the local community.

We also learn about participatory research from G. De Landscheere's "Universal History of Experimental Pedagogy" (1995). It aims to make the members of the group involved in the investigation process as active as possible, and the concern for "social action takes precedence over all others". In the following we will present the six characteristics of participatory research (G. De Landscheere, 1995, p. 265):

- The problem appears in the community that defines it, analyzes it and solves it.

- The ultimate goal of research is to radically transform social reality and improve the lives of those involved. The beneficiaries of the research are therefore the members of the community. 
- Participating research requires the full and complete participation of the community throughout the research process.

- The participatory research process can raise participants' awareness of their own resources and mobilize them for endogenous development.

- It is a method of research more scientific than traditional research, in the sense that community participation facilitates a more precise and authentic analysis of social reality.

- The researcher is an employed participant here; he learns during research. He militates instead of seeking separation.

Another conception refers to participatory-action research. It usually has clear goals and unites people who are affected by a problem. Students, parents, teachers participate in the planning, analysis and application of research results of common interest, create special situations, solving real problems, involving creativity. Through participatory-action research, there is a rapprochement, a fusion between theoretical and practical research, influencing each other.

$\mathrm{R}$. Bezede, claims, that action research was implemented in education in the 30s of the century. XXth century, the initiative aimed at including scientists and practitioners in conducting investigations in the school environment. "In a broad sense, it refers to a reflective investigation on the development of the instructionaleducational process at the level of the students' class" (Bezede, 2014, p. 5).

Action research represents (adapted from R. Bezede):

$\Rightarrow$ a research that can be implemented by teachers to solve problems and gain experience in the field of education;

$\Rightarrow$ involves the application of systematic observations at the level of the students' class, the accumulation of information for their use in decision-making and the implementation of didactic strategies, innovative teaching techniques;

$\Rightarrow$ a way to research the state of affairs at the level of the educational institution, in order to identify optimal solutions for its functioning;

$\Rightarrow$ a part of the pedagogical activity. Teachers are in a situation when they are constantly following the students, gathering information, improving the learning process and the atmosphere in the class of students / school by changing the outdated working methods. Action research makes them better understand under what conditions, why and in what way, students can achieve excellent learning outcomes.

"Thus, action research can be defined as a set of investigative methodologies, which promote both action and research equally and at the same time" (Bezede, 2014 , p. 6.) The same author, is of the opinion, that through the action-research method we could investigate everything related to the field of the education system. "Curriculum development at school decision, methods used, ways of interac- 
tion in the classroom, school or community, alternative assessment systems, own training, all, along with many other elements can be addressed for improvement through the research-action methodology" (Bezede, 2014).

Action research can also be applied as a way of self-assessment with visible consequences at institutional and individual level. it can also be applied as a way of self-assessment with visible consequences at institutional and individual level.

In the paper "Action research in education", the researcher A. Nedelcu (2011, pp. 42-43) talks about the "fields of pedagogical reflection and action in education in Europe", which refers to:

$\circ$ the theoretical (philosophical) foundations of education (on what basis do we educate?);

○ the objectives of education (for what purpose do we educate?) (Achieving "key competences", with everything that this process involves);

○ the content of education (by resorting to what exactly do we educate?);

o educational practices - (how exactly do we educate?);

$\circ$ quality monitoring and evaluation (how well do we do what we do?) - setting high standards and indicators;

$\bigcirc$ the role and quality of human resources in education (who educates and how?);

○ participatory policy formulation mechanisms (how do we plan and decide?

$\begin{gathered}\text { Areas of } \\ \text { investigation } \\ \text { through action } \\ \text { research }\end{gathered}$
$\begin{aligned} & \text { teaching methods - replacing a traditional method with } \\ & \text { one's own discovery; }\end{aligned}$
$\begin{aligned} & \text { learning strategies - adopting an integrated approach to the } \\ & \text { learning process instead of a monocurricular focused } \\ & \text { approach; }\end{aligned}$
$\begin{aligned} & \text { evaluation procedures - improvement of continuous } \\ & \text { evaluation methods; }\end{aligned}$
$\begin{aligned} & \text { attitudes of values - encouraging more positive attitudes at } \\ & \text { work or changing students' value systems regarding some } \\ & \text { aspects of life; }\end{aligned}$
$\begin{aligned} & \text { continuous professional development of teachers - } \\ & \text { improving teaching skills, developing new learning } \\ & \text { methods, increasing analytical skills, strengthening self- } \\ & \text { confidence; }\end{aligned}$
$\begin{aligned} & \text { the managerial system - the gradual introduction of } \\ & \text { techniques aimed at behavioral changes; }\end{aligned}$
$\begin{aligned} & \text { the administrative system - increasing the efficiency of } \\ & \text { certain aspects of school life. }\end{aligned}$

Fig. 1.1 Areas of investigation through action research

(A. Nedelcu, Action research in education) 
From the figure above, we can see that continuous professional development involves a change in teaching style, the teacher is looking for innovative methods, increasing self-confidence and developing research skills. It is important to mention that the research competence is developed in parallel, both for the teacher and for the students, because the teacher is primarily concerned with the development of skills in his students.

The action research is carried out in a spiral, with a regular verification of the initial plan, with repeated stages of action, monitoring, evaluation, reflection of the initiated process.

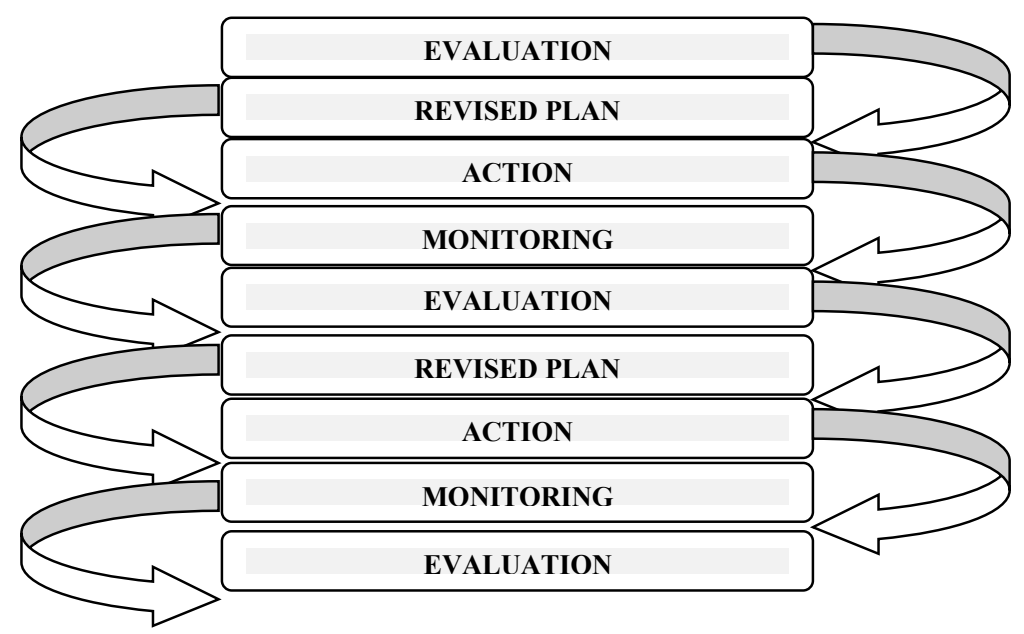

\section{Fig. 1.2 Phases of action research}

\section{(A. Nedelcu, Action research in education)}

From the figure above, we deduce the idea that we undertake action research based on a plan, which can be revised in order to obtain an improvement.

In the same vein, we will present a series of conditions that would facilitate action research (adapted from C. Ulrich, 2002):

- implies the principle of volunteering;

- is largely organized and outlined by the teacher;

- researches the daily school aspects (findings, observations at class or school level);

- is an adaptable and transformative activity;

- opens strategic perspectives;

- involves a group collaboration activity;

- is made and evaluated by the teacher; 
- a lasting partnership is expected: colleagues, experts, researchers;

- during the research the information is collected, evaluated, discussed and acted on its basis. Information is directly related to observation and behavior;

- reflections are based on personal knowledge of the situation;

- is a lighter version of the research;

- action research phases are designed and executed in a spiral and applied in a spiral: planning, action, observation, reflection, revision, improvement.

In the educational process, action research can be treated from several points of view, with possibilities for development or achievement in the near future. It can be carried out at the level of a class, of several classes or at the level of an institution. R. Bezede (2014, p. 6), reproduces this subject as follows:

\begin{tabular}{|c|c|c|c|}
\hline Action research & The research professor & Participatory research & $\begin{array}{c}\text { Research at school } \\
\text { level }\end{array}$ \\
\hline $\begin{array}{c}\text { Expected changes } \\
\text { Changes in student } \\
\text { grade level }\end{array}$ & $\begin{array}{c}\text { Changes in one or } \\
\text { more parallel classes or } \\
\text { similar profiles }\end{array}$ & $\begin{array}{c}\text { Improving school } \\
\text { activity; emphasis on } \\
\text { a curricular area of } \\
\text { common interest }\end{array}$ \\
\hline $\begin{array}{c}\text { People / groups of } \\
\text { people }\end{array}$ & Teacher & Two or more teachers & The whole school \\
\hline Impact & $\begin{array}{c}\text { The experience can } \\
\text { extend beyond the } \\
\text { classroom }\end{array}$ & $\begin{array}{c}\text { Initiating new teacher } \\
\text { partnerships }\end{array}$ & $\begin{array}{c}\text { Great potential for re- } \\
\text { structuring and change } \\
\text { within the school }\end{array}$ \\
\hline
\end{tabular}

Table 1.1 Action research, approached from several perspectives (R. Bezede, Professional development of teachers through the implementation of action research)

From the table above, we can conclude that action research is carried out with the involvement of several educational actors and has a positive impact by creating stable partnerships of teachers and visible restructuring in the educational institution.

Recommendation of the Council of the European Union (2018), Education Code of the Republic of Moldova (2014), Education Development Strategy 20142020, Standards for Continuing Education of Teachers (2007), Standards of Professional Competence of Teachers in General Education (2016), The National Curriculum modernized in the history of Romanians and Universal for high school (2010), the National Curriculum reconceptualized in history for high school (2019), is a set of regulatory acts that guide teachers in their professional activity. 
In 2018, the Council of the European Union comes up with a new Recommendation on key competences for lifelong learning, the 2006 Recommendation being revised and updated. According to the latest document, eight key competencies are established (2018, pp.7-8):

- literacy skills;

- multilingual skills;

- skills in science, technology, engineering and mathematics;

- digital skills;

- personal, social and learning skills to learn;

- citizenship skills;

- entrepreneurial skills;

- skills of awareness and cultural expression.

We would like to mention that key competencies are interdependent, influencing each other. Teaching problems can no longer be solved by a single teacher in a discipline, but only together with colleagues, by applying transdisciplinary training. Skills in science, technology, engineering and mathematics could be developed by teachers of exact sciences: biology, mathematics, physics, computer science. And teachers of history, Romanian language, geography and foreign languages should participate in various trainings, round tables, workshops, organized in their own educational institutions, so that later they can successfully carry out extracurricular classes and activities.

Literacy competence "involves reading and writing skills and a good understanding of written information and therefore requires a person's knowledge of vocabulary, functional grammar and language functions" (Council of Europe Recommendation, 2018, p. 8).

The student must distinguish, use different sources, search, select and process information. It is also important to formulate and express it orally, and in writing in an appropriate way. The ultimate goal of the teacher should be to develop critical thinking in students, "the ability to evaluate information and work with it" (ibidem).

Through action research we can solve a number of problems: starting with functional illiteracy and ending with the application of innovative methods. Among the difficulties we faced at the high school level is functional illiteracy, which means that some students have difficulty reading and understanding messages in textbooks and historical sources. The most annoying fact is that the students can lag far behind their more advanced colleagues, if the teacher does not intervene in time to rectify the situation. It is this category of students who can complete the list of those who fail at school, ie who fail to take a positive note in the subjects of study. 
If the given situation persists until the 5th-7th grades, we can expect that the respective students will remain correct in several disciplines and will not be able to take any exam. This topic, as part of a pedagogical issue, has been addressed several times in high school teachers' councils. We decided to study the phenomenon in question, analyzing the students' results in the PISA test (Program for International Assessment of Students).

Researching the topic of functional illiteracy for several years, we found that we are dealing with students from disadvantaged families, or who do not care about the education of children. In some advanced countries, the basics of intellectual work start in kindergarten, from the age of 3-4. In our country, however, the situation is slightly different. Often, we notice that students aged 11-12, but also those aged 15-16, have a limited vocabulary, can not clearly formulate their thoughts, because they do not possess the techniques of intellectual work. Obviously, we try to involve parents in the children's training activity, but we do not always get the expected result.

To help weaker students cope with various historical sources, we have developed a strategy, consisting of four stages:

In the first stage - The student is guided in the correct use of the textbook and other available sources, and trained in various reading techniques, which are presented by the Romanian scientist I. Cerghit (2006, p. 179):

$\checkmark$ explanatory reading (explanation of misunderstood words (by derivation, context),

$\checkmark$ selective reading - targeting basic ideas;

$\checkmark$ slow reading, deepening - reflecting on the essentials;

$\checkmark$ critical reading - based on personal observations;

$\checkmark$ problematized reading forming our question-problem;

$\checkmark$ assimilation reading accompanied by repetitions based on understanding the material;

$\checkmark$ fast and efficient reading.

The expected effect would be: knowledge of notions, formulation of statements. At the second stage - The student is monitored by the teacher in selecting the information.

The result would be: the ability to process information using different sheets, schematic notes, graphs, diagrams, drawings, summaries, etc.

At the third stage - Enriching the student's vocabulary by repeatedly reading the texts, making oral, written speeches, essays, compositions, essays, etc.

At the 4 th stage - Elements of critical thinking appear (issuing own ideas, conclusions, proposals, etc. 


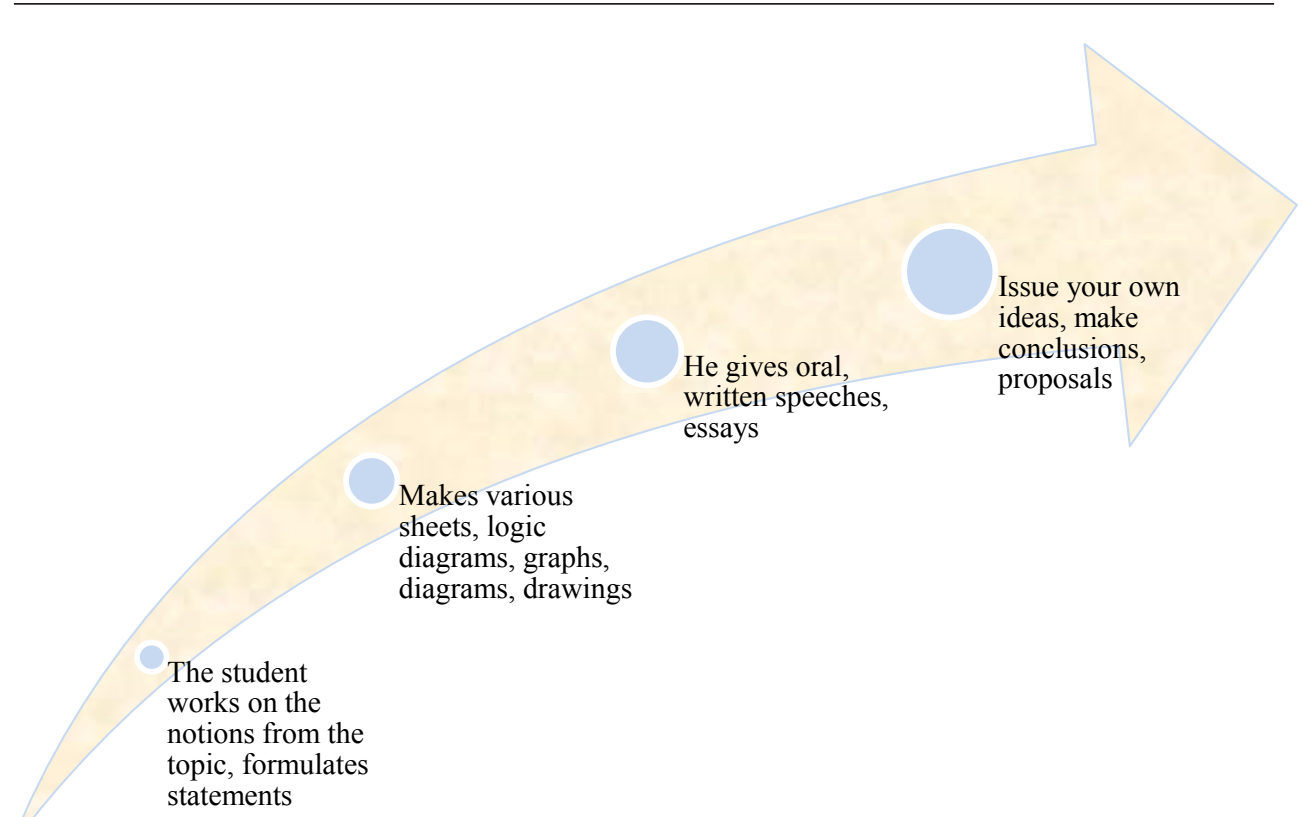

\section{Fig. 1.3 Developing students' literacy skills}

(from professional experience)

From the scheme proposed above we can observe a positive evolution in the development of literacy competence. The student gradually progresses from working with a single source (textbook), to the use of several bibliographic sources, which helps him to overcome the barriers of expressing opinion, analysis and synthesis on the text read.

We will see the results of the work over a longer period of time, but we must be patient and consistent in what we do. It is important to take small steps, but sure of our success.

Through the literacy competence we can also develop the research competence of both teachers and students, because it involves a creative intellectual effort to find answers, which are not known at the beginning of the investigation.

We develop the research competence through:

a) motivating students to investigate;

b) involvement in research projects (based on the topics studied or about different historical personalities, members of students' families, different events that changed people's lives. For example: deportations from MSSR, famine in 19461947;

c) stimulating group research, in order to promote team spirit and cooperation in students; 
d) making scientific trips: in archives, museums, libraries;

e) participation in various scientific conferences at local, national, international level.

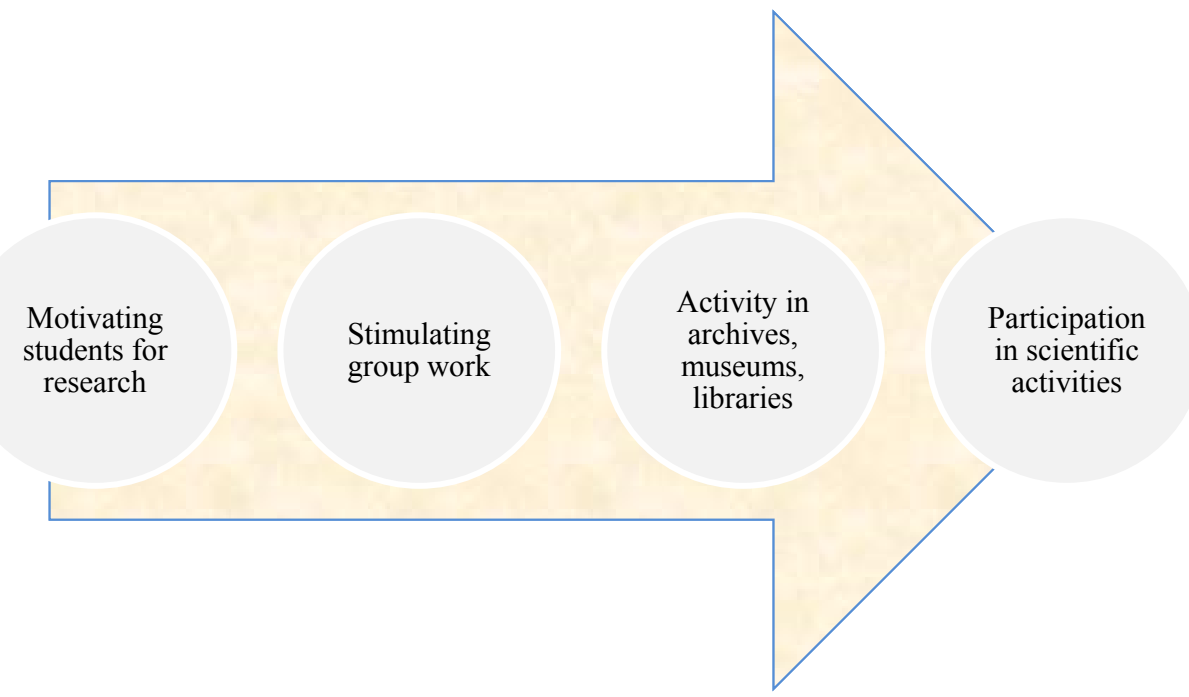

Fig. 1.4 Development of research competence in students

(from professional experience)

The forms of research can be varied: journal-chronicle, essay, Power Point presentation.

Thus, through action research we can develop literacy skills, scientific skills and other skills, which has a beneficial influence on the multilateral development of students.

The Romanian author E. Păun (2002) is of the opinion that action research changes the role of the teacher. In addition to the role of "practitioner", the teacher also appears as a "researcher". It gives him opportunities to improve his professional experience, another vision of success and the class of students. The action research model can be implemented in several cases, but the results obtained will be different, depending on the situation created and the people involved in the research process. Action research is a malleable process of planning, action, observation, reflection, being guided by a person involved in the given problem. At the same time, it is a process of revising the initial plan, with repeated stages of action of the research / action process. The same author considers (2002, p. 131) that:

- Research-action improves the relationship theory - practice - research;

- Stimulates the professional development of the teaching staff and develops the culture of collaboration in school; 
- Involvement of teachers in collecting and interpreting data about their own practice generates increased responsibility, acceptance and acceptance of change;

- Conducting action research in schools involves low costs and long-term effects, given the ability of teachers as researchers of their own practice;

- The results of such research are reflected not only on the classroom or school, but can also have a strong impact on the community; they can inform and inspire the change measures initiated by education decision-makers.

In conclusion, we can say that each of the three concepts presented and analyzed in this article are good to be used by teachers in solving difficulties and improving professional practices.

\section{References}

Bezede R. (2014). Professional development of teachers through the implementation of action research. In: D. Bogdea (ed.), Didactica Pro. Chişinau: Educational Center.

Cara A., Guțu Vl., Gremalschi A., Solovei R. (2007). Standards for continuous training of teachers in general secondary education. Chişinau: Cartier Publishing House.

Cerghit I. (2006). Teaching methods. Iași: Polirom Publishing House.

Dawe R.H. (1991). Fundamentals of lifelong learning. Bucharest: Didactic and Pedagogical Publishing House.

De Landsheere G. (1995). The universal history of experimental pedagogy. Bucharest: Didactic and Pedagogical Publishing House.

Dewey J. (1992). Fundamentals for a science of education. Bucharest: Didactic and Pedagogical Publishing House.

Education Code of the Republic of Moldova (2014). In: Official Gazette of the Republic of Moldova.

Education Development Strategy for 2014-2020 "Education-2020”. (2014). Official Gazette of the Republic of Moldova, no. 345-351.

European Union Recommendation. (2018). Retrieved from: https://eur-lex.europa. eu/legal-content/RO/TXT/PDF/?uri=CELEX:32018H0604(01)\&from=LT. [Accessed on 25.07.2020].

National Curriculum (2010). History for cl. a X-a-XII. Chişinau: Știința Publishing House.

National Curriculum (2019). Romanian History and Universal cl. X-a-XII. Chişinau: Ministry of Education, Culture and Research of the Republic of Moldova.

Nedelcu A. (2011). Action research in education. Bucharest: Publishing House. 
Păun E., Potolea D. (2002). Theoretical foundations and applied approaches. Iași: Publishing House Polirom.

Sclifos L. (2014). Action research-an opportunity to face new challenges in education. In: D. Bogdea (ed.), Didactica Pro. Chişinau: Educational Center.

Standards of professional competence of teachers in general education. (2016). Chişinau: Ministry of Education of the Republic.

Ulrich C. (2002). Reform at school level - challenges and possibilities. In: Pedagogy. Theoretical foundations and applied approaches. Iași: Polirom Publishing House.

\section{Rozwój zawodowy nauczycieli poprzez zaangażowanie w badania naukowe}

\section{Streszczenie}

Pod koniec XX wieku w edukacji pojawiły się trzy koncepcje funkcjonalne, które opierają się na partycypacyjnym podejściu do badań: badania w działaniu, badania partycypacyjne, badania $\mathrm{w}$ działaniu partycypacyjnym. Wydaje się, że tego typu badania byłyby bardzo przydatne w pracy nauczycieli. W artykule przedstawiono kilka sugestii dotyczących rozwoju umiejętności czytania i pisania wśród uczniów w kontekście rozwoju zawodu nauczyciela. W teksie zauważono, iż tylko dzięki konstruktywnej współpracy nauczycieli z kolegami ze szkoły jest się w stanie przeprowadzić wartościowe badania.

Słowa kluczowe: rozwój zawodowy, badania naukowe, partycypacja naukowa, szkolne niepowodzenia. 